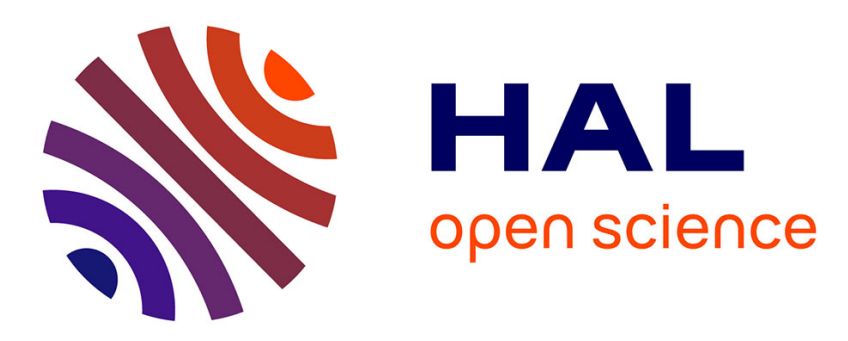

\title{
Functional diversity in European estuaries: Relating the composition of fish assemblages to the abiotic environment
}

\author{
D. Nicolas, Jérémy Lobry, Olivier Le Pape, Philippe Boët
}

\section{- To cite this version:}

D. Nicolas, Jérémy Lobry, Olivier Le Pape, Philippe Boët. Functional diversity in European estuaries: Relating the composition of fish assemblages to the abiotic environment. Estuarine, Coastal and Shelf Science, 2010, 88 (3), p. 329 - p. 338. 10.1016/j.ecss.2010.04.010 . hal-00584043

\section{HAL Id: hal-00584043 \\ https://hal.science/hal-00584043}

Submitted on 7 Apr 2011

HAL is a multi-disciplinary open access archive for the deposit and dissemination of scientific research documents, whether they are published or not. The documents may come from teaching and research institutions in France or abroad, or from public or private research centers.
L'archive ouverte pluridisciplinaire HAL, est destinée au dépôt et à la diffusion de documents scientifiques de niveau recherche, publiés ou non, émanant des établissements d'enseignement et de recherche français ou étrangers, des laboratoires publics ou privés. 
Author produced version of the article published in

Estuarine Coastal and Shelf Science, 2010, vol. 88, p. 329 - 338

The original publication is available at http://sciencedirect.com/

doi : 10.1016/j.ecss.2010.04.010

\title{
Functional diversity in European estuaries: relating the
} composition of fish assemblages to the abiotic environment

\author{
Nicolas, D. ${ }^{1 *}$, Lobry, J. ${ }^{1}$, Le Pape, O. ${ }^{2} \&$ Boët, P. ${ }^{1}$ \\ ${ }^{1}$ Cemagref, UR EPBX, 50 av. de Verdun, F-33612 Cestas, France \\ ${ }^{2}$ Université Européenne de Bretagne, UMR 985 Agrocampus Ouest, Inra «Ecologie \& Santé des Ecosystèmes », \\ Ecologie halieutique, Agrocampus Ouest, 65 rue de St Brieuc, CS 84215, 35042 Rennes, France. \\ *Corresponding author delphine.nicolas@cemagref.fr
}

\begin{abstract}
Based on a large standardised dataset, the present study proposed a meta-analysis to describe general patterns in the functional diversity of estuarine fish assemblage in terms of both number of species and density along the European Atlantic coast. Fish species collected from 31 European estuaries from Portugal to Scotland were allocated to functional groups according to their ecological utilization of estuaries. A clustering analysis was performed to compare the overall functional structure of estuaries based on fish composition. Generalised linear models were computed to identify relationships between large-scale abiotic and intraestuarine descriptors and functional attributes of estuarine fish assemblages. The total number of species, and more especially of marine species, was higher in larger estuaries with a wide entrance and, locally, in polyhaline waters. The total density was mainly related to the proportion of intertidal mudflats and, locally, was greater in mesohaline waters. In terms of relative density, northern systems were dominated by marine and catadromous species, while estuarine species were prevalent in the southern ones.
\end{abstract}

\section{Keywords}

Functional diversity, fish assemblage, Europe, tidal estuaries, habitat, glm 
Author produced version of the article published in

Estuarine Coastal and Shelf Science, 2010, vol. 88, p. 329 - 338

The original publication is available at http://sciencedirect.com/

doi : 10.1016/j.ecss.2010.04.010

Estuaries constitute essential habitats for many fish species to complete their life cycle. While it is recognised that both diadromous and estuarine resident fish species truly depend on estuaries (Ray, 2005), most species originating from the marine environment (McLusky and Elliott, 2006) exploit these areas in a more opportunistic manner (Lenanton and Potter, 1987). Estuaries act temporarily as nursery and feeding areas, especially for marine juveniles, offering a highly nutrient rich environment and shallow turbid refuges suitable to their development (Blaber and Blaber, 1980; Potter et al., 1990). Man uses estuarine goods and services intensively, enhancing trophic resource depletion and habitat degradation, e.g. through fishing, embankments and organic and metal contaminations (Le Pape et al., 2007; Dauvin, 2008). As estuarine environments are naturally characterised by enrichment in organic matter and high variability of abiotic conditions, anthropogenic stresses are difficult to distinguish from natural ones (Elliott and Quintino, 2007). The sustainability of estuarine ecosystem functions relies on a good understanding of ecological processes and the choice of adequate and efficient management measures. Fish species present a wide diversity of biological cycles and ecological compartments, making them relevant integrated indicators to reflect estuarine conditions at multiple spatial and temporal scales (Whitfield and Elliott, 2002). Their life strategies related to their ecological use of estuarine habitats supposedly reflect the functioning of estuaries (Elliott et al., 2007). Relating the functional diversity in fish assemblages to the natural abiotic variability would constitute a starting point for better identifying estuarine fish assemblage reference conditions, to analyse subsequently the human-induced impacts and to assess the ecological status of estuarine ecosystems (Coates et al., 2007; Courrat et al., 2009; Delpech et al., in press).

Functional attributes have been widely used to describe estuarine fish assemblages (e.g. Claridge et al., 1986; Potter et al., 1990; Elliott and Dewailly, 1995; Elliott et al., 2007; Franco et al., 2008). In such a classification, fish species that have similar features in resource 
Author produced version of the article published in

Estuarine Coastal and Shelf Science, 2010, vol. 88, p. 329 - 338

The original publication is available at http://sciencedirect.com/

doi : 10.1016/j.ecss.2010.04.010

1 exploitation are assigned to the same functional group (Blondel, 2003). This functional

2 approach allows to reduce the complexity of fish assemblages and to focus on the use made

3 by fish of estuarine environments and, thus, on the ecological functions of estuaries (Garrison

4 and Link, 2000). In addition, categorization based on functionality rather than taxonomic

5 attributes, allows the comparison of fish assemblages belonging to different biogeographical

6 areas (Elliott et al., 2007). In the present study, functional groups related to fish ecological use

7 of estuaries and reflecting salinity preference and migration behaviour (Elliott et al., 2007;

8 Franco et al., 2008) were used to analyse the functional diversity of fish assemblages in 31

9 European tidal estuaries. From the ichtyofauna analysis of 17 European estuaries of the

eastern Atlantic seaboard, Elliott and Dewailly (1995) concluded that estuarine fish

11 assemblages typically consist of "a majority equally of estuarine resident, marine adventitious

12 and marine juveniles (25\% each), with a small number of marine seasonal migrant,

diadromous and freshwater adventitious species". Based on readjusted estuarine use

14 categories, Franco et al. (2008) found a similar pattern for 38 estuaries from the

Mediterranean to the Baltic regions. On the contrary, Selleslagh et al. (2009) used a homogenous fish data set that allowed a quantitative analysis of 15 Atlantic French estuaries and found that estuarine (54\%) and marine migrant (33\%) fish dominated assemblages in autumn in terms of relative number of individuals. Based on a larger standardised data set, the aim of the present paper was to check whether estuarine fish assemblages along the European Atlantic coast fit with a functional pattern both in terms of number of species and fish density per guild of estuarine use. The second objective was to identify the degree of variation in the functional composition of fish communities in relation to large-scale abiotic descriptors of the estuarine environment and to salinity gradients. In particular, the following questions are addressed: Do larger estuaries shelter a higher species diversity (number of species and/or fish densities per functional group) compared to smaller estuaries? Do species richness and 
Author produced version of the article published in

Estuarine Coastal and Shelf Science, 2010, vol. 88, p. 329 - 338

The original publication is available at http://sciencedirect.com/

\section{2. Materials and Methods}

\subsection{Acquisition and analyses of abiotic data}

4 A total number of 31 European tidal estuaries from Portugal to Scotland (Fig.1) were

5 described by large scale abiotic descriptors using an ecohydrology approach (Nicolas et al., 6 2010). Estuaries were characterised by several types of descriptors (Table 1): latitude; five continuous geomorphological quantitative variables (watershed area, estuarine water area, estuary mouth width and depth and continental shelf width); three geomorphological class factors (intertidal area type, main nature of littoral substrate and wave exposure), and two hydrological continuous variables (tidal range and mean annual river discharge).

A normed principal component analysis (PCA) combined with a hierarchical clustering procedure was performed on all of these abiotic descriptors (Nicolas et al., 2010). Annual river discharge, watershed area and estuary area were log-transformed to lessen the influence of the few higher values on the many lower ones. The aim of this analysis was to highlight groups of estuaries with similar physical characteristics and select synthetic and uncorrelated variable(s) to describe fish communities.

\subsection{Fish data}

\subsubsection{Collection, classification and selection of fish data}

As specified by Nicolas et al. (2010), a large fish data set based on sampling surveys in the scope of the European Water Framework Directive (WFD, European Council Directive, 2000) was stored in a database. The present study only focuses on beam trawl surveys (i.e. 1 estuary $\times 1$ year $\times 1$ season) carried out in spring and autumn between 2005 and 2007, during which salinity was measured and a total area of at least $2500 \mathrm{~m}^{2}$ (Nicolas et al., 2010) was sampled. A total of 878 trawls from 48 surveys were selected. These samples were categorised into three salinity classes (SC): oligohaline (salinity <5), mesohaline (salinity 
Author produced version of the article published in

Estuarine Coastal and Shelf Science, 2010, vol. 88, p. 329 - 338

The original publication is available at http://sciencedirect.com/

doi : 10.1016/j.ecss.2010.04.010

1 between 5 and 18) and polyhaline (salinity >18), as simplified from the Venice classification

2 system (Courrat et al.,2009).

3 Each caught fish was identified at species level. In Spanish Basque systems, Gobiidae species

4 from Pomatoschistus genera were not determined and could correspond to different species.

5 To counteract this bias, all Pomatoschistus were considered to represent one unique estuarine

6 resident species. Each of the other species was assigned to a category related to their estuarine use. Elliott et al. (2007) emphasized the need for a standardisation of functional typologies and proposed an estuarine use functional group that may be applied to any parts of the world.

Our functional classification corresponded to the one adapted by Franco et al. (2008) from

Elliott et al. (2007) to the European estuarine waters. The different categories were: estuarine species (ES); marine migrants (MM); marine stragglers (MS); anadromous species (AN); catadromous species (CA) and freshwater species (FS). The allocation of a species to one specific category was based on both previously mentionned sources and local expert

flounder Platichthys flesus and the thinlip grey mullet Liza ramada. While P. flesus was classified either as catadromous (Lobry et al., 2003; Kottelat and Freyhof, 2007), marine migrant (Thiel et al., 2003; Franco et al., 2008) or estuarine resident (Elliott and Dewailly, 1995; Selleslagh et al., 2009), L. ramada was either catadromous (Elliott and Dewailly, 1995; Franco et al., 2008; Selleslagh et al., 2009) or marine migrant (Potter and Hyndes, 1999).

These species can spend a long lifetime within estuaries (Potter and Hyndes, 1999; Elliott et al., 2007). However, since they were observed to spawn at sea and to be able to enter freshwater (Kottelat and Freyhof, 2007), they were grouped in the catadromous category together with the European eel Anguilla anguilla (Tsukamoto et al., 2002).

\subsubsection{Calculation of fish assemblage descriptors}

Abundances were divided by the corresponding trawl sampled surface. These resulting densities of individuals (ind. $1000 \mathrm{~m}^{-2}$ ) were summed per functional group and per trawl 
Author produced version of the article published in

Estuarine Coastal and Shelf Science, 2010, vol. 88, p. 329 - 338

The original publication is available at http://sciencedirect.com/

doi : 10.1016/j.ecss.2010.04.010

1 sample then, taking into account their underlying lognormal distribution, log-transformed to

2 reduce the influence of exceptionally high densities. These log-transformed densities

$3 \ln ($ Dens +1$)$ per functional group were averaged per survey then per estuary (pool of seasons

4 and years) to compare the overall functional structure among estuaries. In a second approach

5 analysing intra-estuarine processes, these indices were averaged at the salinity class scale

6 (three classes per survey quite systematically, per season and estuary). Similarly, the total

7 number of species (SR for species richness) was calculated per functional group and per

8 survey and the same operation was carried out at the scale of the salinity class. Next, the

9 number of species was divided by the log-transformed total sampled surface $\left(\mathrm{m}^{2}\right)$ carried out

during a survey $(\mathrm{S})$ or per salinity class $\left(\mathrm{S}_{\mathrm{sc}}\right)$ to standardise species richness in relation to

11 sampling effort (Nicolas et al., 2010). Consequently, indices based on species richness were referred to as $S R / \ln (S)$ or $S R / \ln \left(S_{s c}\right)$. To compare standardised values of species richness between estuaries, the number of species is expressed for a theoretical $1000 \mathrm{~m}^{2}$ trawl haul.

\subsubsection{Clustering analyses of estuaries based on fish assemblage descriptors}

Analyses were carried out in terms of both number of species and density of individuals per functional group per estuary (pool of seasons and years). Groups of estuaries displaying similar functional composition were highlighted through a hierarchical clustering analysis using the Ward agglomerative method based on square-root-transformed Bray-Curtis similarity matrices (Faith et al., 1987; Legendre and Andersson, 1999). The groups and distances to centroids were plotted on the first axes of a principal coordinate analysis (PCoA), using the function betadisper[vegan] on the $\mathrm{R}$ software ( $\mathrm{R}$ Development Core Team, 2005). For each identified cluster of estuaries, the relative functional composition in density and species richness were analysed. 
Author produced version of the article published in

Estuarine Coastal and Shelf Science, 2010, vol. 88, p. 329 - 338

The original publication is available at http://sciencedirect.com/

doi : 10.1016/j.ecss.2010.04.010

1 Patterns in the standardized estimates of species richness and fish densities, globally and per

functional group, averaged per season and estuary then per salinity class, were analysed to

identify the degree of variation in the functional composition of a fish assemblage related to identification of best explanatory descriptors was based on generalised linear models. Preliminary graphic tests on data distribution showed that the Gaussian law was the most suitable to model both $S R / \ln \left(S_{s c}\right)$ and $\ln ($ Dens +1$)$ indices. To reduce the presence of zerovalues while still keeping an ecological relevance, marine migrant and marine straggler species were pooled together as marine species (M) and catadromous and anadromous species as diadromous species (DIA, Table 1). Freshwater species, rarely present and in low densities, were not modelled.

Within models, we introduced factors related to the sampling procedure, when significant, in order to account for possible bias; these factors correspond to between-seasons and betweensalinity-types variability. The between-years effect was not considered because most estuaries were sampled in one year only. This is the reason why, when an estuary was sampled over two years, data were averaged per season then per salinity class. Thereafter, abiotic descriptors $\left(\mathrm{X}_{\mathrm{i}}\right)$ were added to the models, so that the GLM could be written as follows: Indices $=$ Season $+\mathrm{SC}+\mathrm{X}_{1} \ldots+\mathrm{X}_{\mathrm{i}} \ldots+\mathrm{X}_{\mathrm{n}}$

The method used to select the best combination of abiotic descriptors was similar to Nicolas et al. (2010). Each preselected descriptor was first tested separately in models. To select the best explicative variables from among the significant ones, a stepwise procedure was used. The best final combination of descriptors was determined according to analyses of variance (Chi-square test at 5\% level), Akaike Information Criterion (Sakamoto et al., 1986), ecological relevance and graphical analysis of residuals. The nature of the effect of the continuous explicative variables (i.e. positive or negative) on fish indices was identified from 
Author produced version of the article published in

Estuarine Coastal and Shelf Science, 2010, vol. 88, p. 329 - 338

The original publication is available at http://sciencedirect.com/

doi : 10.1016/j.ecss.2010.04.010

according to their corresponding coefficient and the difference between two adjoining

modalities was checked with a student test (at $5 \%$ level).

\section{Results}

\subsection{Abiotic contrasts among estuaries and preselection of potentially explanatory}

\section{descriptors}

7 The PCA plot based on abiotic data $(60.2 \%$ of total inertia for the first two main components, Fig. 2) discriminated five distinct clusters of estuaries (hereafter referred as 'clusters').

Cluster A consisted of the smallest estuaries with a very narrow continental shelf, including the seven Spanish estuaries, the Goyen and Seudre (France), and the Mira (Portugal). Localised within the English Channel, estuaries from cluster B were characterized by low depth at the river mouth, high proportion of intertidal area and a very wide continental shelf. Cluster C pooled estuaries of intermediate size: three French estuaries in the Bay of Biscay and the two Scottish systems (the Forth and Tay). Cluster D consisted of the largest southern systems, characterized by mesotidal estuaries of moderate size associated with a huge watershed and a warm, dry climate. Last, the three widest French systems (cluster E) presented the highest river discharge.

The correlation circle (Fig. 2) highlighted the strong positive correlations between mean annual river discharge, watershed area and estuary area $(0.68<\mathrm{r}<0.92$, p-value $<0.0001)$ and between estuary area and entrance width $(r=0.69$, $p$-value $<0.0001)$. Mean annual river discharge, which reflected the overall system size, was selected for further tests of the effect of system size on fish assemblage attributes. Entrance width, which informed on the connectivity of the estuary with the marine environment, was used as an indicator of marine influence. Latitude, continental shelf width and tidal range were also positively correlated $(0.61<\mathrm{r}<0.76, \mathrm{p}$-value $<0.0001)$ : continental shelf width and tidal range increased from the 
Author produced version of the article published in

Estuarine Coastal and Shelf Science, 2010, vol. 88, p. 329 - 338

The original publication is available at http://sciencedirect.com/

doi : 10.1016/j.ecss.2010.04.010

1 width was selected for further analyses of fish assemblages. The semi-quantitative intertidal

2 class factor, which was negatively related to the entrance depth variable, $(r=-0.4, p$-value $<$

3 0.05), was the last selected descriptor. As most estuaries (58\%) were well protected against

4 waves, the wave exposure factor did not discriminate estuaries. Finally, the littoral substrate

5 class factor was redundant with the continental shelf width effect.

\subsection{Relative functional composition of estuarine fish assemblages}

Over the entire study area, a total of 109 species from 42 different families were identified: estuarine, $5.5 \%$ anadromous and $3 \%$ catadromous species (Table 2).

Regarding the functional composition in terms of number of species, estuaries were categorised into three clusters (hereafter referred as 'groups', Fig. 3). Group I, which comprised most of the largest systems classed in clusters D and E (except the Douro estuary, Fig. 2), had the greatest number of species (with an average \pm confidence interval of $13 \pm 1$ for a $1000 \mathrm{~m}^{2}$ trawl haul), while the group III, comprising five small systems from clusters A and $\mathrm{B}$, had the lowest species diversity ( $\mathrm{SR}=5 \pm 2$ species). On average, estuarine fish assemblages in both groups I and II included all functional modalities and were largely dominated by marine species (i.e. MM and MS, on average $60.4 \%$ in relative proportion), and more particularly by marine migrant species $(38.6 \pm 2.4 \%$ of the total number of species). On the contrary, group III was characterised by the absence of species with a freshwater origin, i.e. anadromous and freshwater species, and was rather mainly occupied by estuarine species $(60.6 \pm 20 \%)$.

In terms of density, two groups were distinguished among the estuaries (Fig. 4). All functional attributes were represented in the estuaries of the first group, while in the second, species with a freshwater origin (FS and AN) were lacking. In group I (Fig. 4), individuals from marine migrant species and catadromous species were the major contributors to total 
Author produced version of the article published in

Estuarine Coastal and Shelf Science, 2010, vol. 88, p. 329 - 338

The original publication is available at http://sciencedirect.com/

doi : 10.1016/j.ecss.2010.04.010

1 density with a relative proportion of $31.7 \pm 3.7 \%$ and $21.7 \pm 4.1 \%$, respectively. By contrast,

estuaries categorised in group II were largely dominated by the density of estuarine species

the three largest southernmost systems (cluster D).

Anadromous species were present in half of the studied estuaries and were best represented in terms of density in the northernmost Tay (24\%) and Forth (32.2\%) estuaries. Freshwater species were found in eleven French systems, where they were low both in number (on average $\mathrm{SR}=1.4 \pm 0.7$ freshwater species per $\left.1000 \mathrm{~m}^{2}\right)$ and in density of individuals $(14.6 \pm$ $5.4 \%$ of total catch).

10

\subsection{Links between the functional composition of fish assemblage and the abiotic estuarine}

\section{environment}

Salinity class significantly influenced total species richness in estuaries (Table 3a). The polyhaline area displayed on average the highest total number of species ( $\mathrm{SR}=80 \pm 11$ for a $1000 \mathrm{~m}^{2}$ trawl haul) compared to the oligo- and mesohaline areas (50 \pm 8 species). Contrary to marine and estuarine species, the diadromous species were more numerous in oligo- and mesohaline areas $(\mathrm{SR}=14 \pm 3$ species $)$ than in the salty downstream $(10 \pm 3$ species, Table 3a). Most of the freshwater individuals (84\%) were caught in the oligohaline area. The annual mean river discharge further explained the total number of species and the number of marine species with a positive effect (Table 3a). The three largest systems categorised in cluster E of Fig. 2 had a much higher total number of species ( $\mathrm{SR}=15 \pm 3$ species) than the small estuaries grouped in cluster A (6 \pm 2 species). In addition, entrance width was positively related to the total number of species and to the number of diadromous species (Table 3a).

Fish density in the mesohaline area $\left(64 \pm 42\right.$ ind.1000m $\left.\mathrm{m}^{-2}\right)$ was significantly higher, particularly for marine species, than in the oligohaline $(36 \pm 22)$ and polyhaline areas $(22 \pm 7$, Table 3b). Density of diadromous fish was higher both in oligo- and mesohaline areas (16.5 \pm 
Author produced version of the article published in

Estuarine Coastal and Shelf Science, 2010, vol. 88, p. 329 - 338

The original publication is available at http://sciencedirect.com/

doi : 10.1016/j.ecss.2010.04.010

19.5 ind. $\left.1000 \mathrm{~m}^{-2}\right)$ than in polyhaline areas $\left(3.7 \pm 1.3\right.$ ind. $1000 \mathrm{~m}^{-2}$, Table $\left.3 \mathrm{~b}\right)$. The relative

2 intertidal area also explained a statistically significant part of variability in the total fish

3 density and more especially the density of marine and estuarine species (Table $3 b$ ). Estuaries

4 with the greatest proportion of intertidal mudflats $(80-100 \%$ of total estuary area) had the

5 highest densities $\left(61 \pm 31\right.$ ind. $\left.1000 \mathrm{~m}^{-2}\right)$, in particular with comparison to estuaries with less

6 than $20 \%$ of intertidal mudflats $\left(20 \pm 15\right.$ ind. $\left.1000 \mathrm{~m}^{-2}\right)$. Entrance width had a further positive

7 effect on the total density, the density of marine species and the density of diadromous species

8 (Table 3b). Finally, continental shelf width also had a positive effect on diadromous species

9 density (Table 3b), which was four times higher in the eastern Channel estuaries $(25.7 \pm 23.8$

10 ind. $\left.1000 \mathrm{~m}^{-2}\right)$ than elsewhere $\left(6.2 \pm 2.2\right.$ ind $\left..1000 \mathrm{~m}^{-2}\right)$.

\section{Discussion}

\subsection{Prerequisites for a large-scale comparison of estuarine fish assemblages}

A relevant and consistent comparison of estuarine fish assemblages on a large scale requires standardised fish data in relation to the type of fishing gear used, the sampling effort and the sampling period. Compared to the previous large scale qualitative analyses of European estuarine fish assemblages (Elliott and Dewailly, 1995; Franco et al., 2008), the present data set, based solely on beam trawl samples, was more homogenous. However, differences in the dimensions of the net, mesh size and weight exist between the beam trawls used for different surveys, according to the country and the size of estuaries (Nicolas et al., 2010). Trawl samples could also differ due to haul duration and speed. Thus, this absence of a standardised sampling protocol within the WFD framework still enhances heterogeneity problems for statistical analyses and dampens accuracy of the analysis. Nonetheless, by applying a transformation to both species richness (Nicolas et al., 2010) and abundance data based on the 
Author produced version of the article published in

Estuarine Coastal and Shelf Science, 2010, vol. 88, p. 329 - 338

The original publication is available at http://sciencedirect.com/

doi : 10.1016/j.ecss.2010.04.010

1 sufficiently standardised to compare fish assemblages in both qualitative and quantitative

terms.

3 Latitudinal variability in fish reproduction and recruitment peaks together with seasonal

4 patterns in migratory activities was expected to influence results (Potter and Hyndes, 1999;

5 Selleslagh et al., 2009). Nevertheless, among the 31 studied estuaries, the between-season

6 variability was never found significant in the models. Pooling spring and autumn in the

7 present comparative analyses appeared relevant and enabled us to consider a large data set,

8 since only $42 \%$ of the estuaries were sampled at both seasons.

9 Regarding the functional description of fish species, such large-scale comparison requires clear definitions of the chosen functional groups and standardised allocations for each species (Elliott et al., 2007). Nonetheless, as detailed for $P$. flesus and L. ramada species in the Materials and Methods section, the allocation of some species to a specific functional group can differ greatly from an author to another. Moreover, because of local fish behavioural adaptations, Franco et al. (2008) recommended the use of flexible allocations for one species to account for its associated geographical variability. For most of the identified fish species, especially when they are of no fisheries interest, further research on their biology is required at local level to allocate species to guilds according to region. As a consequence, these inconsistencies in functional attributions may have a marked influence on the results. For instance, Selleslagh et al. (2009), found for the three French Eastern English Channel Canche, Authie and Somme estuaries, a mean relative proportion of estuarine individuals of $43 \%$. But, when allocating P. flesus as catadromous and not as estuarine species as done Selleslagh et al. (2009), this proportion was reduced by $10 \%$. Nevertheless, even if these problems of allocation generate uncertainty, general patterns can be inferred from the present study. 
Author produced version of the article published in

Estuarine Coastal and Shelf Science, 2010, vol. 88, p. 329 - 338

The original publication is available at http://sciencedirect.com/

doi : 10.1016/j.ecss.2010.04.010

1 Like the composition of fish assemblages found by Elliott and Dewailly (1995), the present

2 estuarine fish assemblages were composed of a small number of diadromous and freshwater

3 species and a majority of marine migrant, marine straggler and estuarine species. The large

4 proportion of marine, and more precisely marine migrant species, and especially their juvenile

5 stage, emphasised the great importance of estuaries as fish nursery grounds (e.g. Elliott and

6 Dewailly, 1995; Potter and Hyndes, 1999; Laffaille et al., 2000; Franco et al., 2008; Courrat

7 et al., 2009) and their role in maintaining coastal stocks (Rochette et al., in press).

8 Nonetheless, contrary to Elliott and Dewailly's study (1995), these marine and estuarine

9 species were not present in equal proportions in all estuaries. Although Elliott and Dewailly

(1995) advanced 'common patterns of estuarine usage irrespective of the differences between

the estuaries', the present analyses highlighted different patterns among estuaries in terms of

both number of species and density. Large-scale abiotic gradients were shown to significantly influence the functional diversity of fish assemblages:

\subsubsection{The effect of system size and entrance width on species richness}

In terms of number of species, the clustering analysis emphasised that larger systems presented a higher functional diversity and a higher total number of species. This relationship between species richness and system size was confirmed by the GLM analyses and has already been reported in other worldwide studies (Monaco et al., 1992; Pease, 1999; Harrison and Whitfield, 2006; Nicolas et al., 2010). Nevertheless, while system size slightly influenced the number of marine species, it did not explain the number of estuarine or diadromous species. The increase in the total number of species according to the size of the estuarine system is often related to a diversity of habitats (Monaco et al., 1992; Wootton, 1998; Nicolas et al., 2010). However, this hypothesis requires further tests to determine whether the heterogeneity of estuarine habitats influences the total number of species (Pihl et al., 2002). Here, the width at the mouth further promoted total species richness, which tends to confirm that the enhancement of high-salinity habitats favoured the exploitation of the estuary by 
Author produced version of the article published in

Estuarine Coastal and Shelf Science, 2010, vol. 88, p. 329 - 338

The original publication is available at http://sciencedirect.com/

doi : 10.1016/j.ecss.2010.04.010

1 more different species (Nicolas et al., 2010). Furthermore, the positive influence of entrance

2 width on the density of marine species suggests that further seawater penetration raises the

3 migration and concentration of some marine individuals into estuaries. The entrance width

4 also promoted diadromous migrant species both in terms of number of species and of density,

5 probably due to the attraction of diadromous species for large fluvial plumes (Boehlert and

6 Mundy, 1988; Tosi et al., 1990; Tosi and Sola, 1993). Nonetheless, as confirmed from the

7 present analysis, the distribution of diadromous species, and more especially of anadromous

species, are also related to biogeographical aspects, including homing and population decline

(McDowall, 1988).

\subsubsection{The contrast between northern and southern estuaries in terms of density}

In terms of relative density, the clustering analysis revealed that northern systems sheltered fish of all estuarine use categories and were dominated by marine and catadromous species (group I, Fig. 4), while southern systems were dominated by estuarine species (group II, Fig. 4). The GLM analyses also revealed higher densities of diadromous species in northern estuaries and more particularly in the eastern English Channel compared to southern systems. However, these analyses did not demonstrate a latitudinal contrast in the density of estuarine species. Models showed that estuaries in the English Channel, which generally display a high percentage of intertidal area, exhibited among the highest densities in both marine and estuarine species. Thus, although southern estuaries were dominated by estuarine species, the density of these species appeared nonetheless higher in northern English Channel systems.

Claridge et al. (1986) found that estuarine species represented only $0.6 \%$ of the total catch in the inner Severn estuary. Potter and Hyndes (1999) presumed the situation was similar in all macrotidal holarctic estuaries and explained this low representation of estuarine species as a result of their strong hydrodynamics that prevent the eggs and larvae being able to remain inside the estuary. However, the present dataset showed that even in the widest megatidal Loire and Seine estuaries, estuarine species were well represented, with 11 and $14.5 \%$ 
Author produced version of the article published in

Estuarine Coastal and Shelf Science, 2010, vol. 88, p. 329 - 338

The original publication is available at http://sciencedirect.com/

doi : 10.1016/j.ecss.2010.04.010

1 respectively of the total catch, moreover for high total densities in these systems. Moreover,

2 southern systems (group II, Fig. 4) were clearly dominated by estuarine species which

3 represented on average $45 \%$ of total species richness (from $31 \%$ in the Mira estuary to $100 \%$

4 in the Urumea estuary). In contrast to the northern systems, these southern systems were

5 characterised by a reduced freshwater influence due to a warmer and drier climate and by

6 small tidal exchanges. This higher hydrological steadiness associated with high salinity values

7 appears to provide a more favourable environment for the recruitment of resident species

8 (Potter and Hyndes, 1999). This may explain the high representation of estuarine individuals

9 in southern estuaries and the low number of species with freshwater affinities, i.e.

anadromous and freshwater species. Accordingly, comparing sampling surveys carried out in

the Tejo estuary between 1979 and 2002, Costa et al. (2007) showed that the density of estuarine species and marine species was higher in dry years than in wet ones. Martinho et al. (2007) reported that a severe drought occurred between summer 2003 and June 2006 in Portugal and observed subsequently an increase in marine stragglers in the Mondego estuary. Consequently, higher temperatures appeared to promote species with marine affinities (i.e. marine and estuarine species, Potter and Hyndes, 1999; Costa et al., 2007). In future analyses, it would be interesting to test the effect of both water temperature and river discharges on a more simultaneous temporal scale.

\subsubsection{The effect of intertidal area on density}

21 The intertidal area type was the factor that accounted for the greatest deviance in total density, and more especially in density of marine and estuarine species. Elliott and Taylor (1989a; $1989 \mathrm{~b}$ ) found in the Forth estuary that the biomass and the production of macrofauna per unit area were higher in the intertidal mud-flats than in the subtidal area. Most fish in estuaries have been shown to feed on benthic invertebrates (de Sylva, 1975; Elliott and Taylor, 1989b; Costa and Elliott, 1991); the intertidal areas constitute the dominant feeding area for the 
Author produced version of the article published in

Estuarine Coastal and Shelf Science, 2010, vol. 88, p. 329 - 338

The original publication is available at http://sciencedirect.com/

doi : 10.1016/j.ecss.2010.04.010

1 estuarine fish populations (Costa and Elliott, 1991) and promote fish density. Both estuarine

2 and marine species, and more particularly juveniles, preferred shallow systems with extensive

3 intertidal mudflats, generally turbid, where they can find great food availability and reduced

4 predation pressure (Blaber and Blaber, 1980). This also underlined the fact that small

5 estuaries with a high proportion of intertidal flats could be as important as larger systems for

6 their nursery function, displaying on average higher fish density per unit area (e.g. $44.9 \pm 15.1$ ind. $1000 \mathrm{~m}^{-2}$ in the Authie estuary $v s 4.5 \pm 1.2$ ind.1000 $\mathrm{m}^{2}$ in the Gironde estuary). The loss of intertidal area through channelization or land reclamation in these estuaries might thus have a heavy impact on fish production, as demonstrated in the Forth (McLusky et al., 1992) and the Seine (Rochette et al., in press) estuaries.

\subsection{Intra-estuarine organisation of fish assemblages: the effect of the salinity gradient}

The present study highlighted the intra-estuarine structure of the fish assemblages in terms of

both number of species and density. While the upper low-salinity estuary areas were dominated by freshwater and diadromous species, the lower high-salinity parts contained a majority of marine and estuarine species. As expected, and highlighted in other studies (Potter et al., 1990; Thiel et al., 1995; Pease, 1999), a high-salinity area promoted species richness. This result further emphasises that large estuaries, which often present the entire range of haline habitats, may exhibit greater total species richness (Nicolas et al., 2010).

On the other hand, the total maximum fish density was observed in the middle mesohaline parts of estuaries, where intertidal mudflats that display a high carrying capacity (Elliott and Taylor, 1989b; Costa and Elliott, 1991) might predominate. Indeed, in estuarine mesohaline areas, where the environmental conditions are especially harsh (i.e. high variability in hydrodynamics, salinity, turbidity and sediment erosion/deposition), few species are physiologically able to colonize, inducing a low biological competition but high abundances 
Author produced version of the article published in

Estuarine Coastal and Shelf Science, 2010, vol. 88, p. 329 - 338

The original publication is available at http://sciencedirect.com/

doi : 10.1016/j.ecss.2010.04.010

the presence of fine sediment particles (Harris and Heap, 2003; McLusky and Elliott, 2006)

with a high content of organic matter, which are particularly suitable for the development of

These great abundances of benthic preys may be the origin of the observed location of the

high fish density (Nicolas et al., 2007). The high density of marine species in the same mesohaline parts may also be partly related to a reduction in osmoregulation energy cost for lower salinities (Potter et al., 1990). In contrast, the density of estuarine species, which are by definition well-adapted to the high variability of the estuarine environment, appeared not to be influenced by salinity, as found in other single-site studies (Henderson and Holmes, 1991;

Power et al., 2000). The density of diadromous species, able to osmoregulate, was higher in

11 both meso- and oligohaline estuary areas, while, as expected (Franco et al., 2008), the freshwater species were restricted to the oligohaline areas.

\section{Conclusions}

The present study highlighted four main trends in the functional diversity of fish assemblages: (1) system size and entrance width, which facilitate seawater penetration, promoted functional diversity and the total number of species by enhancing density and number of marine species; (2) northern estuaries were dominated by marine and catadromous species, while estuarine resident species were prevalent in southern estuaries, potentially due to more stable hydrology and higher temperature; (3) estuaries consisting for the most part of intertidal mudflats were further highlighted as having a crucial role of nursery and trophic support for juvenile fish; (4) fish assemblages were structured by the salinity gradient: high-salinity habitats concentrated maximum species richness, consisting mainly of marine and estuarine species, mesohaline habitats exhibited the greatest total density and especially the greatest density of marine species; low-salinity habitats had the greatest density of diadromous species and could also present some freshwater species. 
Author produced version of the article published in

Estuarine Coastal and Shelf Science, 2010, vol. 88, p. 329 - 338

The original publication is available at http://sciencedirect.com/

doi : 10.1016/j.ecss.2010.04.010

1 Finally, despite the highly variable and complex functioning of estuaries that tends to hide

2 anthropogenic impacts (the estuarine quality paradox, Elliott and Quintino, 2007), general

3 patterns in fish assemblages reflecting natural variability can be distinguished. As a result,

4 when developing fish indicators to assess the level of anthropogenic pressures in estuaries

5 (Courrat et al., 2009; Delpech et al., in press), considering significant natural explanatory

6 descriptors such as system size, entrance width and salinity would greatly improve pressure-

7 impact models and the precision of fish-based indicators. Moreover, these descriptors are, for most of them, easily available. Nonetheless, to improve the understanding of the relationship between fish and their environment, more precise investigations at a smaller habitat scale should be carried out.

\section{Acknowledgements}

This project was supported by the Cemagref institute and the French Aquitaine region. We are very grateful to all our European partners for sharing their WFD fish data: Steve Coates, Adam Waugh from Environmental Agency (London, England and Wales data), Alexis Pearce from Scottish Environment Protection Agency (Edinburgh, Scotland data), Angel Borja from AZTI - Tecnalia/Marine Research Division (Pasaia, Spain Basque data), Maria José Costa from Institute of Oceanography (Lisbon, Portugal data), Rachid Amara and Jonathan Selleslagh from University of Opale littoral coast (Wimereux, French Authie and Canche estuaries data) and Mario Lepage, Michel Girardin and Jacques Massé from Cemagref institute (Cestas, French data). Special thanks to Hilaire Drouineau for sharing his statistical knowledge. 
Author produced version of the article published in

Estuarine Coastal and Shelf Science, 2010, vol. 88, p. 329 - 338

The original publication is available at http://sciencedirect.com/

doi : 10.1016/j.ecss.2010.04.010

References:

Blaber, S.J.M. and Blaber, T.G., 1980. Factors affecting the distribution of juvenile estuarine and inshore fish. Journal of Fish Biology 17, 143-162.

Blondel, J., 2003. Guilds or functional groups: Does it matter? Oikos 100, 223-231.

Boehlert, G.W. and Mundy, B.C., 1988. Roles of behavioural and physical factors in larval and juvenile fish recruitment to estuarine nursery areas. American Fisheries Society Symposium 3, 51-67.

Claridge, P.N., Potter, I.C. and Hardisty, M.W., 1986. Seasonal changes in movements, abundance, size composition and diversity of the fish fauna of the Severn estuary. Journal of the Marine Biological Association of the United Kingdom 66, 229-258.

Coates, S., Waugh, A., Anwar, A. and Robson, M., 2007. Efficacy of a multi-metric fish index as an analysis tool for the transitional fish component of the Water Framework Directive. Marine Pollution Bulletin 55, 225-240.

Costa, M.J. and Elliott, M., 1991. Fish usage and feeding in two industrialised estuaries - the Tagus, Portugal, and the Forth, Scotland. In: Elliott, M. and Ducrotoy, J.P. (Eds), Estuaries and coasts : spatial and temporal intrecomparisons. Olsen and Olsen, Fredensborg, Denmark, pp. 289-297.

Costa, M.J., Vasconcelos, R., Costa, J.L. and Cabral, H.N., 2007. River flow influence on the fish community of the Tagus estuary (Portugal). Hydrobiologia 587, 113-123.

Courrat, A., Lobry, J., Nicolas, D., Laffargue, P., Amara, R., Lepage, M., Girardin, M. and Le Pape, O., 2009. Anthropogenic disturbance on nursery function of estuarine areas for marine species. Estuarine, Coastal and Shelf Science 81, 179-190.

Dauvin, J.-C., 2008. The main characteristics, problems, and prospects for Western European coastal seas. Marine Pollution Bulletin 57, 22-40.

de Sylva, D.P., 1975. Nektonic food webs in estuaries. In: Cronin, L.E. (Ed.), Estuarine Research: Chemistry, Biology and the Estuarine System. Academic Press, New York, pp. 420-447.

Delpech, C., Courrat, A., Pasquaud, S., Lobry, J., Le Pape, O., Nicolas, D., Boët, B., Girardin, M. and Lepage, M., in press. Development of a fish-based index to assess the ecological quality of transitional waters: the case of French estuaries. Marine Pollution Bulletin In Press, Corrected Proof.

Eisma, D. and Cadee, G.C., 1990. Particulate matter processes in estuaries. Biogeochemistry of major world rivers, 283-296.

Elliott, M. and Dewailly, F., 1995. The structure and components of European estuarine fish assemblages. Netherlands Journal of Aquatic Ecology 29, 397-417.

Elliott, M. and Quintino, V., 2007. The Estuarine Quality Paradox, Environmental Homeostasis and the difficulty of detecting anthropogenic stress in naturally stressed areas. Marine Pollution Bulletin 54, 640-645.

Elliott, M. and Taylor, C.J.L., 1989a. The production ecology of the subtidal benthos of the Forth Estuary, Scotland. Scientia Marina 53, 531-541.

Elliott, M. and Taylor, C.J.L., 1989b. The structure and functioning of an estuarine/marine fish community in the Forth estuary, Scotland. In: Klekowski, R.Z., Styczynska, E. and Falkowski, L. (Eds), Proceedings of the 21st European Marine Biology Symposium. Polish Academy of Sciences, Gdansk, pp. 227-240.

Elliott, M., Whitfield, A.K., Potter, I.C., Blaber, S.J.M., Cyrus, D.P., Nordlie, F.G. and Harrison, T.D., 2007. The guild approach to categorizing estuarine fish assemblages: A global review. Fish and Fisheries 8, 241-268.

European Council Directive, 2000. Directive 2000/60/EC of the European Parliament and of the Council of 23 October 2000 establishing a framework for Community action in the field of water policy. Official Journal of the European Communities 43, 75. 
Author produced version of the article published in

Estuarine Coastal and Shelf Science, 2010, vol. 88, p. 329 - 338

The original publication is available at http://sciencedirect.com/

doi : 10.1016/i.ecss.2010.04.010

1 Faith, D.P., Minchin, P.R. and Belbin, L., 1987. Compositional dissimilarity as a robust

2 measure of ecological distance. Vegetatio 69, 57-68.

3 Franco, A., Elliott, M., Franzoi, P. and Torricelli, P., 2008. Life strategies of fishes in

4 European estuaries: the functional guild approach. Marine Ecology Progress Series 354, 219-

5228.

6 Garrison, L.P. and Link, J.S., 2000. Dietary guild structure of the fish community in the

7 Northeast United States continental shelf ecosystem. Marine Ecology Progress Series 202,

8 231-240.

9 Harris, P.T. and Heap, A.D., 2003. Environmental management of clastic coastal depositional

environments: inferences from an Australian geomorphic database. Ocean \& Coastal Management 46, 457-478.

Harrison, T.D. and Whitfield, A.K., 2006. Estuarine typology and the structuring of fish communities in South Africa. Environmental Biology of Fishes 75, 269-293.

Henderson, P.A. and Holmes, R.H.A., 1991. On the population dynamics of dab, sole and flounder within bridgwater bay in the lower severn estuary, England. Netherlands Journal of Sea Research 27, 337-344.

Kottelat, M. and Freyhof, J., 2007. Handbook of European freshwater fishes. Kottelat, Cornol,

Laffaille, P., Feunteun, E. and Lefeuvre, J.C., 2000. Composition of fish communities in a European macrotidal salt marsh (the Mont Saint-Michel Bay, France). Estuarine Coastal and Shelf Science 51, 429-438.

Le Pape, O., Gilliers, C., Riou, P., Morin, J., Amara, R. and Désaunay, Y., 2007. Convergent signs of degradation in both the capacity and the quality of an essential fish habitat: State of the Seine estuary (France) flatfish nurseries. Hydrobiologia 588, 225-229.

Legendre, P. and Andersson, M.J., 1999. Distance-based redundancy analysis: Testing multispecies responses in multifactorial ecological experiments. Ecological Monographs 69, $1-24$.

Lenanton, R.C.J. and Potter, I.C., 1987. Contribution of estuaries to commercial fisheries in temperate Western Australia and the concept of estuarine dependence. Estuaries 10, 28-35.

Lobry, J., Mourand, L., Rochard, E. and Elie, P., 2003. Structure of the Gironde estuarine fish assemblages: a European estuaries comparison perspective. Aquatic Living Resources 16, 4758.

Martinho, F., Leitao, R., Viegas, I., Dolbeth, M., Neto, J.M., Cabral, H.N. and Pardal, M.A., 2007. The influence of an extreme drought event in the fish community of a southern Europe temperate estuary. Estuarine Coastal and Shelf Science 75, 537-546.

McDowall, R.M., 1988. Diadromy in fishes - Migrations between freshwater and marine environments. Croom Helm, London, UK, 308 pp.

McLusky, D.S., Bryant, D.M. and Elliott, M., 1992. The impact of land-claim on the invertebrates, fish and birds of the Forth estuary. Aquatic conservation: Marine and Freshwater Ecosystems 2, 211-222.

McLusky, D.S. and Elliott, M., 2006. The Estuarine Ecosystem - ecology, threats and management, $214 \mathrm{pp}$.

Monaco, M.E., Lowery, T.A. and Emmett, R.L., 1992. Assemblages of U.S. west coast estuaries based on the distribution of fishes. Journal of Biogeography 19, 251-267.

Moore, D.M., 1978. Seasonal changes in distribution of intertidal macrofauna in the lower Mersey Estuary, U.K. Estuarine and Coastal Marine Science 7, 117-125.

Nicolas, D., Le Loc'h, F., DÃ@saunay, Y., Hamon, D., Blanchet, A. and Le Pape, O., 2007. Relationships between benthic macrofauna and habitat suitability for juvenile common sole (Solea solea, L.) in the Vilaine estuary (Bay of Biscay, France) nursery ground. Estuarine, Coastal and Shelf Science 73, 639-650. 
Author produced version of the article published in

Estuarine Coastal and Shelf Science, 2010, vol. 88, p. 329 - 338

The original publication is available at http://sciencedirect.com/

doi : 10.1016/j.ecss.2010.04.010

1 Nicolas, D., Lobry, J., Lepage, M., Sautour, B., Le Pape, O., Cabral, H., Uriarte, A. and Boët,

2 P., 2010. Fish under influence: a macroecological analysis of relations between fish species

3 richness and environmental gradients among European tidal estuaries. Estuarine, Coastal and

4 Shelf Science 86, 137-147.

5 Pease, B.C., 1999. A spatially oriented analysis of estuaries and their associated commercial

6 fisheries in New South Wales, Australia. Fisheries Research 42, 67-86.

7 Pihl, L., Cattrijsse, A., Codling, I., Mathieson, S., McLusky, D.S. and Roberts, C., 2002.

8 Habitat use by fishes in estuaries and other brackish areas. In: Elliott, M. and Hemingway,

$9 \quad$ K.L. (Eds), Fishes in estuary. Blackwell Science Ltd, London, pp. 54-123.

Potter, I.C., Beckley, L.E., Whitfield, A.K. and Lenanton, R.C.J., 1990. Comparisons between

the roles played by estuaries in the life cycles of fishes in temperate Western Australia and Southern Africa. Environmental Biology of Fishes 28, 143-178.

Potter, I.C. and Hyndes, G.A., 1999. Characteristics of the ichthyofaunas of southwestern Australian estuaries, including comparisons with holarctic estuaries and estuaries elsewhere in temperate Australia: A review. Australian Journal of Ecology 24, 395-421.

Power, M., Attrill, M.J. and Thomas, R.M., 2000. Environmental factors and interactions affecting the temporal abundance of juvenile flatfish in the Thames Estuary. Journal of Sea Research 43, 135-149.

R Development Core Team, 2005. R: a language and environment for statistical 609 computing. R Foundation for Statistical Computing, Vienna, Austria.

Ray, G.C., 2005. Connectivities of estuarine fishes to the coastal realm. Estuarine, Coastal and Shelf Science 64, 18-32.

Rochette, S., Rivot, E., Morin, J., Mackinson, S., Riou, P. and Le Pape, O., in press. Effect of nursery habitat degradation on flatfish population: Application to Solea solea in the Eastern Channel (Western Europe). Journal of Sea Research.

Sakamoto, Y., Ishiguro, M. and Kitagawa, G., 1986. Akaike Information Criterion Statistics. D. Reidel Publishing Company, 290 pp.

Selleslagh, J., Amara, R., Laffargue, P., Lesourd, S., Lepage, M. and Girardin, M., 2009. Fish composition and assemblage structure in three Eastern English Channel macrotidal estuaries: A comparison with other French estuaries. Estuarine, Coastal and Shelf Science 81, 149-159.

Thiel, R., Cabral, H. and Costa, M.J., 2003. Composition, temporal changes and ecological guild classification of the ichthyofaunas of large European estuaries - A comparison between the Tagus (Portugal) and the Elbe (Germany). Journal of Applied Ichthyology 19, 330-342.

Thiel, R., Sepulveda, A., Kafemann, R. and Nellen, W., 1995. Environmental factors as forces structuring the fish community of the Elbe Estuary. Journal of Fish Biology 46, 47-69.

Tosi, L. and Sola, C., 1993. Role of geosmin, a typical inland water odor, in guiding glass eel Anguilla anguilla (L) migration. Ethology 95, 177-185.

Tosi, L., Spampanato, A., Sola, C. and Tongiorgi, P., 1990. Relation of water odour, salinity and temperature to ascent of glass-eels, Anguilla anguilla (L.) : a laboratory study. Journal of Fish Biology 36, 327-340.

Tsukamoto, K., Aoyama, J. and Miller, M.J., 2002. Migration, speciation and the evolution of diadromy in anguillid eels. Canadian Journal of Fisheries and Aquatic Sciences 59, 19891998.

Whitfield, A.K. and Elliott, M., 2002. Fishes as indicators of environmental and ecological changes within estuaries: a review of progress and some suggestions for the future. Journal of Fish Biology 61, 229-250.

Wootton, R.J., 1998. Ecology of teleost fishes. Fish and Fisheries Series. Kluwer Academic Publishers. 
Author produced version of the article published in

Estuarine Coastal and Shelf Science, 2010, vol. 88, p. 329 - 338

The original publication is available at http://sciencedirect.com/

doi : 10.1016/j.ecss.2010.04.010

1 Table 1: List of the abiotic attributes used to describe the estuarine environment, with their

abbreviation and their ranges (minimum - maximum) and their units for quantitative variables

or their classes for class factors.

Table 2: List of fish species caught during the 48 selected European surveys with the estuarine use functional group they were allocated in, their occurrence in percentage and their mean density value ( \pm confidence interval) in number of individuals per $1000 \mathrm{~m}^{2}$.

Table 3: Analysis of deviances for the generalized linear models computed on both (a) number of species (SR) and (b) densities (Dens) of each functional group category used as response variables with regards to selected descriptors (Intro. Var.) of abiotic attributes of estuaries. Df: degrees of freedom; Expl. Dev.: explained deviance in percentage per introduced descriptor. Sig.: significance (Chi square test), *: when p-value <5\%, **: <1\%, ***: $<0.1 \%$. Slope: slope sign when the explicative descriptor was a quantitative variable; for the class factors, all modalities were presented in decreasing order according to their effect. When the difference between two adjoining modalities was significant (student test), the symbol ">" was applied. Abbreviations of descriptors are detailed in Table 1. 
Author produced version of the article published in

Estuarine Coastal and Shelf Science, 2010, vol. 88, p. 329 - 338

The original publication is available at http://sciencedirect.com/

doi : 10.1016/j.ecss.2010.04.010

\section{Table 1}

\begin{tabular}{|c|c|c|}
\hline Abbreviations & Abiotic attributes & Ranges and units or classes \\
\hline \multicolumn{3}{|c|}{ Continuous explaining variables } \\
\hline LAT & Latitude & 37.2 - 56.5 decimal degrees \\
\hline CSW & Continental shelf width & 4 - 284 kilometres \\
\hline LS & Main Littoral substrate & $\begin{array}{l}\text { 1: Mud; 2: Mud/Sand; 3: Sand; 4: } \\
\text { Sand/Gravel; 5: Rock }\end{array}$ \\
\hline TR & Tidal range & 2.9 - 11.8 metres \\
\hline $\mathrm{RD}$ & $\begin{array}{l}\text { Mean annual river } \\
\text { discharge }\end{array}$ & 2 - 960 metres cube per second \\
\hline WA & Watershed area & 105 - 117955 square kilometres \\
\hline EA & Estuary area & 0.5 - 533 square kilometres \\
\hline EW & Entrance width & 0.2 - 16 kilometres \\
\hline ED & Entrance depth & 0.5 - 29 metres \\
\hline \multicolumn{3}{|c|}{ Categorical explaining factors } \\
\hline IA & Intertidal area type & $\begin{array}{l}1: 0-20 \% ; 2: 20-40 \% ; 3: 40-60 \% \\
4: 60-80 \% ; 5: 80-100 \%\end{array}$ \\
\hline WE & Wave exposure & $\begin{array}{l}\text { 1: extremely exposed; } 2 \text { : } \\
\text { moderately exposed; } 3 \text { : sheltered }\end{array}$ \\
\hline $\mathrm{SC}$ & Salinity class & $\begin{array}{l}\text { 1: oligohaline; } 2 \text { : mesohaline; } 3 \text { : } \\
\text { polyhaline }\end{array}$ \\
\hline $\mathrm{S}_{\mathrm{sc}}$ & $\begin{array}{l}\text { Sampled surface per } \\
\text { salinity class }\end{array}$ & $1000-174155$ square kilometres \\
\hline
\end{tabular}


Author produced version of the article published in

Estuarine Coastal and Shelf Science, 2010, vol. 88, p. 329 - 338

The original publication is available at http://sciencedirect.com/

doi : 10.1016/j.ecss.2010.04.010

Table 2

\begin{tabular}{|c|c|c|c|}
\hline Species & $\begin{array}{l}\text { Functional } \\
\text { group }\end{array}$ & $\begin{array}{l}\text { Occurrence } \\
\text { (\% among the } \\
48 \text { surveys) }\end{array}$ & $\begin{array}{c}\text { Mean } \\
\text { density }\end{array}$ \\
\hline Abramis brama & FS & 13 & $5.9 \pm 3.1$ \\
\hline Agonus cataphractus & MS & 8 & $2.6 \pm 2.2$ \\
\hline Alburnus alburnus & FS & 2 & $172.9 \pm 643$ \\
\hline Alosa alosa & $\mathrm{AN}$ & 4 & $0.6 \pm 0.2$ \\
\hline Alosa fallax & $\mathrm{AN}$ & 4 & $0.3 \pm 0.1$ \\
\hline Ameiurus melas & FS & 13 & $0.9 \pm 0.6$ \\
\hline Ammodytes tobianus & MS & 19 & $1.5 \pm 0.4$ \\
\hline Anguilla anguilla & $\mathrm{CA}$ & 56 & $2.1 \pm 0.4$ \\
\hline Aphia minuta & MS & 27 & $4.2 \pm 1.0$ \\
\hline Argyrosomus regius & MS & 6 & $2.6 \pm 0.5$ \\
\hline Arnoglossus imperialis & MS & 2 & $1.1 \pm 0.0$ \\
\hline Atherina boyeri & $\mathrm{ES}$ & 2 & $1.0 \pm 0.0$ \\
\hline Atherina presbyter & MM & 17 & $1.2 \pm 0.3$ \\
\hline Barbus barbus & FS & 6 & $1.3 \pm 0.9$ \\
\hline Blicca bjoerkna & FS & 10 & $11.1 \pm 13.9$ \\
\hline Buglossidium luteum & MS & 6 & $5.3 \pm 6.5$ \\
\hline Callionymus lyra & MS & 29 & $1.7 \pm 0.7$ \\
\hline Callionymus maculatus & MS & 2 & $3.4 \pm 0.0$ \\
\hline Carassius carassius & FS & 2 & $1.8 \pm 2.3$ \\
\hline Chelidonichthys lucernus & MM & 10 & $0.9 \pm 0.4$ \\
\hline Chelon labrosus & MM & 2 & $0.3 \pm 0.0$ \\
\hline Ciliata mustela & ES & 13 & $1.0 \pm 0.3$ \\
\hline Clupea harengus harengus & MM & 15 & $20.0 \pm 16.5$ \\
\hline Conger conger & MS & 2 & $1.2 \pm 0.1$ \\
\hline Crystallogobius linearis & MS & 2 & $0.3 \pm 0.0$ \\
\hline Cyprinus carpio carpio & FS & 2 & $0.9 \pm 0.0$ \\
\hline Dicentrarchus labrax & MM & 65 & $4.4 \pm 0.8$ \\
\hline Dicentrarchus punctatus & MM & 13 & $0.6 \pm 0.2$ \\
\hline Dicologlossa cuneata & MM & 4 & $0.3 \pm 0.0$ \\
\hline Diplodus annularis & MS & 2 & $3.3 \pm 1.8$ \\
\hline Diplodus bellottii & MM & 4 & $1.6 \pm 0.5$ \\
\hline Diplodus cervinus cervinus & MM & 2 & $0.8 \pm 0.0$ \\
\hline Diplodus sargus & MS & 19 & $3.8 \pm 1.7$ \\
\hline Diplodus vulgaris & MS & 13 & $4.9 \pm 1.7$ \\
\hline Echiichthys vipera & MS & 29 & $1.8 \pm 0.7$ \\
\hline Engraulis encrasicolus & MM & 38 & $4.2 \pm 1.3$ \\
\hline Entelurus aequoreus & MS & 4 & $0.9 \pm 0.0$ \\
\hline Eutrigla gurnardus & MM & 2 & $1.4 \pm 0.0$ \\
\hline Gadus morhua & MM & 2 & $1.1 \pm 0.0$ \\
\hline Gaidropsarus vulgaris & MS & 2 & $0.5 \pm 0.4$ \\
\hline Gasterosteus aculeatus aculeatus & $\mathrm{ES}$ & 15 & $0.8 \pm 0.3$ \\
\hline Gobio gobio gobio & FS & 2 & $5.2 \pm 7.3$ \\
\hline Gobius niger & $\mathrm{ES}$ & 40 & $6.0 \pm 2.1$ \\
\hline Gobiusculus flavescens & MS & 2 & $6.5 \pm 5.0$ \\
\hline Gymnocephalus cernuus & FS & 6 & $1.2 \pm 0.8$ \\
\hline Halobatrachus didactylus & MS & 8 & $5.5 \pm 1.7$ \\
\hline Hippocampus guttulatus & $\mathrm{ES}$ & 6 & $0.9 \pm 0.7$ \\
\hline Hippocampus hippocampus & ES & 15 & $1.2 \pm 0.4$ \\
\hline Hyperoplus immaculatus & MM & 2 & $3.7 \pm 0.0$ \\
\hline Hyperoplus lanceolatus & MS & 4 & $1.1 \pm 1.3$ \\
\hline Labrus bergylta & MS & 2 & $1.8 \pm 0.0$ \\
\hline
\end{tabular}


Author produced version of the article published in

Estuarine Coastal and Shelf Science, 2010, vol. 88, p. 329 - 338

The original publication is available at http://sciencedirect.com/

doi : 10.1016/j.ecss.2010.04.010

Lampetra fluviatilis

Lepadogaster lepadogaster

AN

MS

Lepomis gibbosus

FS

Lesueurigobius friesii

MS

Leuciscus leuciscus

FS

Limanda limanda

MM

Lithognathus mormyrus

MS

Liza aurata

$\mathrm{MM}$

Liza ramada

CA

Merlangius merlangus

$\mathrm{MM}$

Merluccius merluccius

MS

Monochirus hispidus

MS

Mullus barbatus barbatus

$\mathrm{MM}$

Mullus surmuletus

Myoxocephalus scorpius

Osmerus eperlanus

Pagrus pagrus

Parablennius gattorugine

Pegusa lascaris

Perca fluviatilis

Petromyzon marinus

Platichthys flesus

Pleuronectes platessa

MM

MM

AN

MS

MS

MS

FS

AN

CA

$\mathrm{MM}$

Pomatoschistus spp

ES

Psetta maxima

MM

Raja clavata

MS

Raja undulata

MS

Rajella fyllae

Rutilus rutilus

Salmo trutta trutta

Sander lucioperca

Sardina pilchardus

Sardinella aurita

Sarpa salpa

Scophthalmus rhombus

Scorpaena notata

Silurus glanis

Solea senegalensis

Solea solea

Sparus aurata

Spinachia spinachia

MS

FS

AN

FS

MM

MS

MM

MM

MS

FS

MM

MM

MM

ES

Spondyliosoma cantharus

MM

Sprattus sprattus sprattus

MM

Squalius cephalus

FS

Symphodus bailloni

MS

Symphodus cinereus

ES

Symphodus melops

MS

Symphodus roissali

MM

Syngnathus acus

ES

Syngnathus rostellatus

ES

Syngnathus typhle

ES

Torpedo torpedo

MS

Trachurus trachurus

MM

Trigla lyra

MM

Trisopterus luscus

$\mathrm{MM}$

Trisopterus minutus

MS

$1.1 \pm 0.7$

8

2

2

4

4

2

4

4

13

31

15

6

2

2

8

2

13

4

4

4

4

2

69

44

94

94

$0.7 \pm 0.0$

$1.6 \pm 0.0$

$2.1 \pm 2.0$

$6.6 \pm 0.0$

$2.8 \pm 2.3$

$1.1 \pm 0.7$

$1.4 \pm 0.7$

$3.0 \pm 1.1$

$2.3 \pm 0.7$

$0.4 \pm 0.1$

$4.0 \pm 1.9$

$0.3 \pm 0.0$

$3.1 \pm 3.3$

$2.2 \pm 0.0$

$5.2 \pm 1.7$

$1.9 \pm 1.1$

$0.9 \pm 0.3$

$2.8 \pm 4.0$

$8.3 \pm 14.4$

$0.2 \pm 0.0$

$10.6 \pm 2.5$

$6.8 \pm 1.9$

$27.1 \pm 6.6$

$1.0 \pm 0.7$

$0.7 \pm 0.4$

$1.2 \pm 0.2$

$0.3 \pm 0.0$

$5.8 \pm 6.0$

$0.7 \pm 0.0$

$2.3 \pm 1.2$

$0.7 \pm 0.5$

$1.5 \pm 0.0$

$1.2 \pm 0.0$

$1.2 \pm 0.4$

$1.2 \pm 0.0$

$0.4 \pm 0.0$

$2.3 \pm 0.6$

$6.3 \pm 1.1$

$1.0 \pm 0.4$

$0.9 \pm 0.2$

$1.8 \pm 0.9$

$15.9 \pm 6.4$

$7.2 \pm 6.6$

$2.3 \pm 1.7$

$7.3 \pm 0.0$

$4.6 \pm 0.1$

$0.8 \pm 1.0$

$2.0 \pm 0.4$

$1.6 \pm 0.3$

$1.5 \pm 0.5$

$1.6 \pm 0.7$

$0.7 \pm 0.4$

$0.2 \pm 0.0$

$4.7 \pm 1.3$

$7.9 \pm 14.2$ 
Author produced version of the article published in

Estuarine Coastal and Shelf Science, 2010, vol. 88, p. 329 - 338

The original publication is available at http://sciencedirect.com/

doi : 10.1016/j.ecss.2010.04.010

Umbrina canariensis

MS

4

$1.0 \pm 1.2$

Zoarces viviparus 
Author produced version of the article published in

Estuarine Coastal and Shelf Science, 2010, vol. 88, p. 329 - 338

The original publication is available at http://sciencedirect.com/

doi : 10.1016/j.ecss.2010.04.010

1 Table 3

$\begin{array}{llll}\text { Intro. Var. } & \text { Df } & \text { Expl. Dev. } & \text { Sign. }\end{array}$

Slope

(a) Models of species richness indices

\begin{tabular}{|c|c|c|c|c|}
\hline \multicolumn{5}{|c|}{ Total $S R / \ln \left(S_{s c}\right) \sim S C+\log (R D)+E W$} \\
\hline $\mathrm{SC}$ & 2 & 16.4 & $* * *$ & \multirow{4}{*}{$\begin{array}{l}\text { SC3 > SC2, SC1 } \\
+ \\
+\end{array}$} \\
\hline$+\log (\mathrm{RD})$ & 1 & 16.8 & \multirow{3}{*}{$\begin{array}{l}* * * \\
* *\end{array}$} & \\
\hline$+\mathrm{EW}$ & 1 & 6.1 & & \\
\hline Residuals & 90 & 60.7 & & \\
\hline \multicolumn{5}{|c|}{$S R \_M / \ln \left(S_{s c}\right) \sim S C+\log (R D)$} \\
\hline $\mathrm{SC}$ & 2 & 36.7 & \multirow{3}{*}{$\begin{array}{l}* * * \\
* * *\end{array}$} & \multirow{3}{*}{$\begin{array}{l}\mathrm{SC} 3>\mathrm{SC} 2>\mathrm{SC} 1 \\
+\end{array}$} \\
\hline$+\log (\mathrm{RD})$ & 1 & 9.7 & & \\
\hline Residuals & 91 & 53.6 & & \\
\hline \multicolumn{5}{|l|}{$S R \_E S / \ln \left(S_{s c}\right) \sim S C$} \\
\hline$\underline{\mathrm{SC}}$ & 2 & 17.9 & \multirow[t]{2}{*}{$* * *$} & \multirow[t]{2}{*}{$\mathrm{SC} 3>\mathrm{SC} 2>\mathrm{SC} 1$} \\
\hline Residuals & 92 & 82.1 & & \\
\hline \multicolumn{5}{|c|}{$S R \_D I A / \ln \left(S_{s c}\right) \sim S C+E W$} \\
\hline $\mathrm{SC}$ & 2 & 9.1 & \multirow{3}{*}{$\begin{array}{l}* * \\
* * *\end{array}$} & \multirow{3}{*}{$\begin{array}{l}\mathrm{SC} 1, \mathrm{SC} 2, \mathrm{SC} 3 \\
+\end{array}$} \\
\hline$+\mathrm{EW}$ & 1 & 26.8 & & \\
\hline Residuals & 91 & 64.1 & & \\
\hline
\end{tabular}

(b) Models of density indices

Total $\ln ($ Dens +1$) \sim S C+I A+E W$

\begin{tabular}{|c|c|c|c|c|}
\hline \\
\hline $\mathrm{SC}$ & 2 & 7.9 & $* *$ & $\mathrm{SC} 2>\mathrm{SC} 1, \mathrm{SC} 3>0$ \\
\hline$+\mathrm{IA}$ & 4 & 23.3 & $* * *$ & IA 5, IA4, IA2, IA $3>$ IA1 \\
\hline$+\mathrm{EW}$ & 1 & 7.9 & $* *$ & + \\
\hline Residuals & 87 & 60.9 & & \\
\hline \multicolumn{5}{|c|}{$\ln ($ Dens_M+1 $) \sim S C+I A+E W$} \\
\hline $\mathrm{SC}$ & 2 & 7.1 & $*$ & $\mathrm{SC} 2>\mathrm{SC} 3, \mathrm{SC} 1$ \\
\hline$+\mathrm{IA}$ & 4 & 17.4 & $* * *$ & IA5, IA4, IA3, IA2, IA1 \\
\hline$+\mathrm{EW}$ & 1 & 8.3 & $* *$ & + \\
\hline Residuals & 87 & 67.2 & & \\
\hline \multicolumn{5}{|l|}{$\ln ($ Dens_ES+1) $\sim I A$} \\
\hline IA & 4 & 17.9 & $* * *$ & IA5, IA3, IA4, IA2, IA1 \\
\hline Residuals & 90 & 82.1 & & \\
\hline \multicolumn{5}{|c|}{$\ln ($ Dens_Dia+1) $\sim S C+C S W+E W$} \\
\hline $\mathrm{SC}$ & 2 & 14.4 & $* * *$ & $\mathrm{SC} 1, \mathrm{SC} 2>\mathrm{SC} 3$ \\
\hline$+\mathrm{CSW}$ & 1 & 17.3 & $* * *$ & + \\
\hline$+\mathrm{EW}$ & 1 & 4.7 & $*$ & + \\
\hline Residuals & 90 & 63.6 & & \\
\hline
\end{tabular}


Author produced version of the article published in

Estuarine Coastal and Shelf Science, 2010, vol. 88, p. 329 - 338

The original publication is available at http://sciencedirect.com/

doi : 10.1016/j.ecss.2010.04.010

Fig. 1: Location of the 31 European tidal estuaries studied. The continuous line off the coast corresponds to the $150 \mathrm{~m}$ deep limit of the continental shelf.

Fig. 2: Projection of the 31 estuaries on the first two main components of the PCA performed on abiotic variables (see Table 1 and Fig. 1 for abbreviations). The correlation circle of active abiotic variables was inserted in the bottom right part. The six clusters were obtained by clustering method using Ward criteria based on the matrix of Euclidean distance between pairs of sites.

Fig. 3: Relative presence of estuarine use categories among estuaries in terms of species richness. a/ Ordination diagram for the principal coordinates analysis (PCoA) based on BrayCurtis similarity matrices performed on the number of species per estuarine use categories, averaged per estuary. b/ Barplot representing in the upper part the relative percentage of estuarine use categories in number of species and in the lower part the total number of species per cluster.

Fig. 4: Relative densities of estuarine use categories among estuaries. a/ Ordination diagram for the principal coordinates analysis (PCoA) based on Bray-Curtis similarity matrices performed on the log-transformed densities of individuals per estuarine use categories, averaged per estuary. b/ Barplot representing in the upper part the relative percentage of estuarine use categories in densities and in the lower part the total mean of log-transformed densities per cluster.

\section{Figures}


Author produced version of the article published in

Estuarine Coastal and Shelf Science, 2010, vol. 88, p. 329 - 338

The original publication is available at http://sciencedirect.com/

doi : 10.1016/j.ecss.2010.04.010

Fig. 1

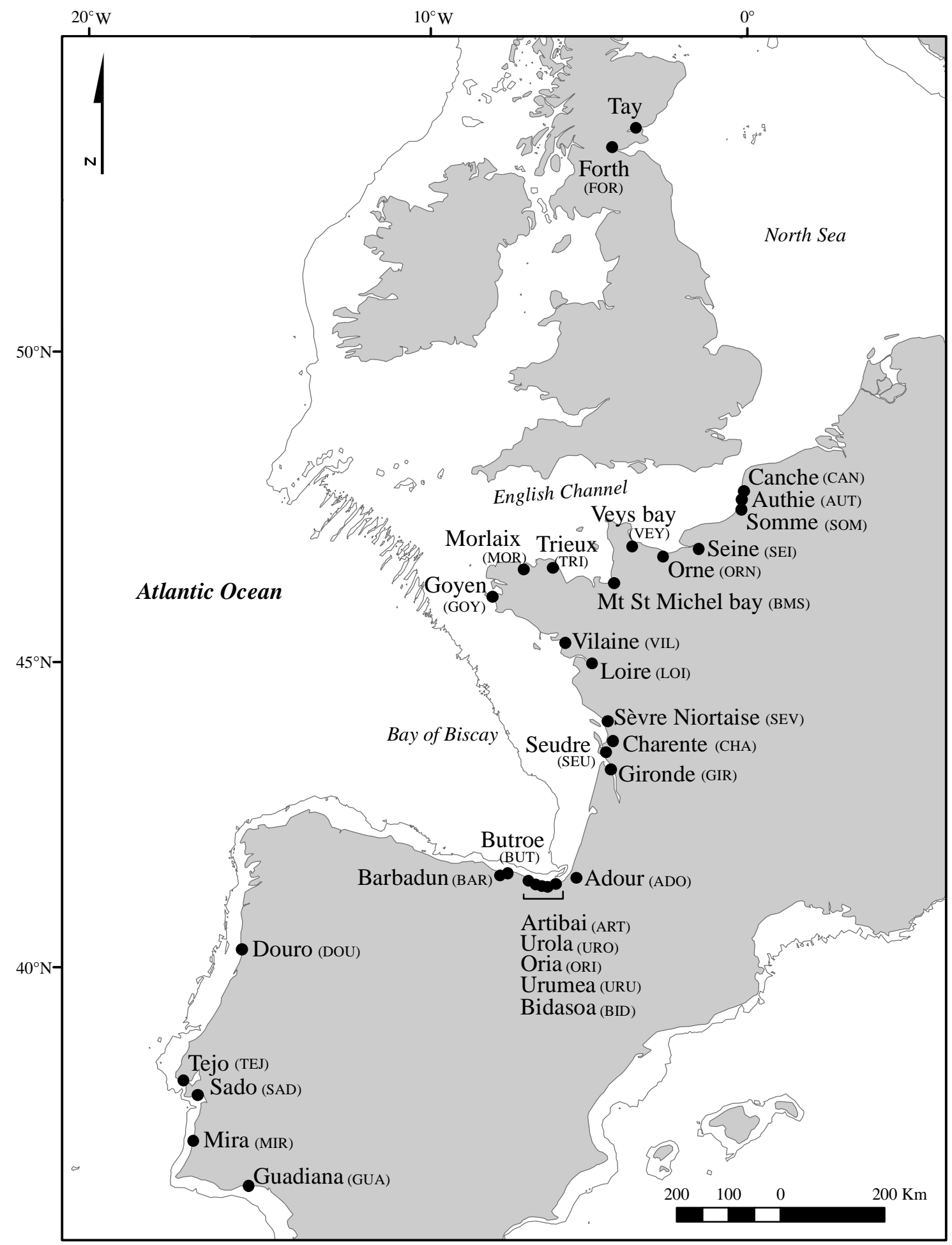


Author produced version of the article published in

Estuarine Coastal and Shelf Science, 2010, vol. 88, p. 329 - 338

The original publication is available at http://sciencedirect.com/

doi : 10.1016/j.ecss.2010.04.010

Fig. 2

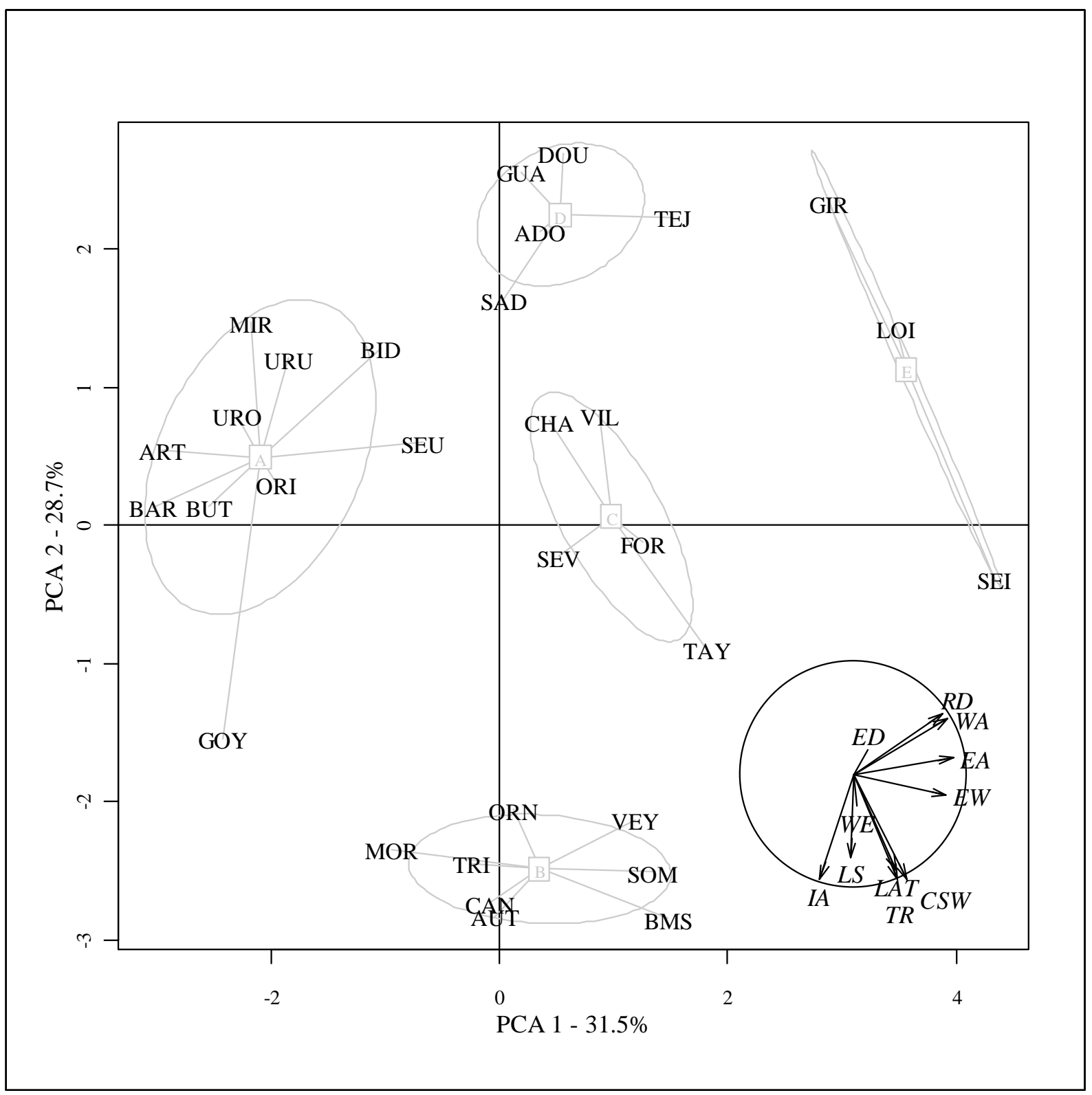

15 
Estuarine Coastal and Shelf Science, 2010, vol. 88, p. 329 - 338

The original publication is available at http://sciencedirect.com/

doi : 10.1016/j.ecss.2010.04.010

Fig. 3

a/

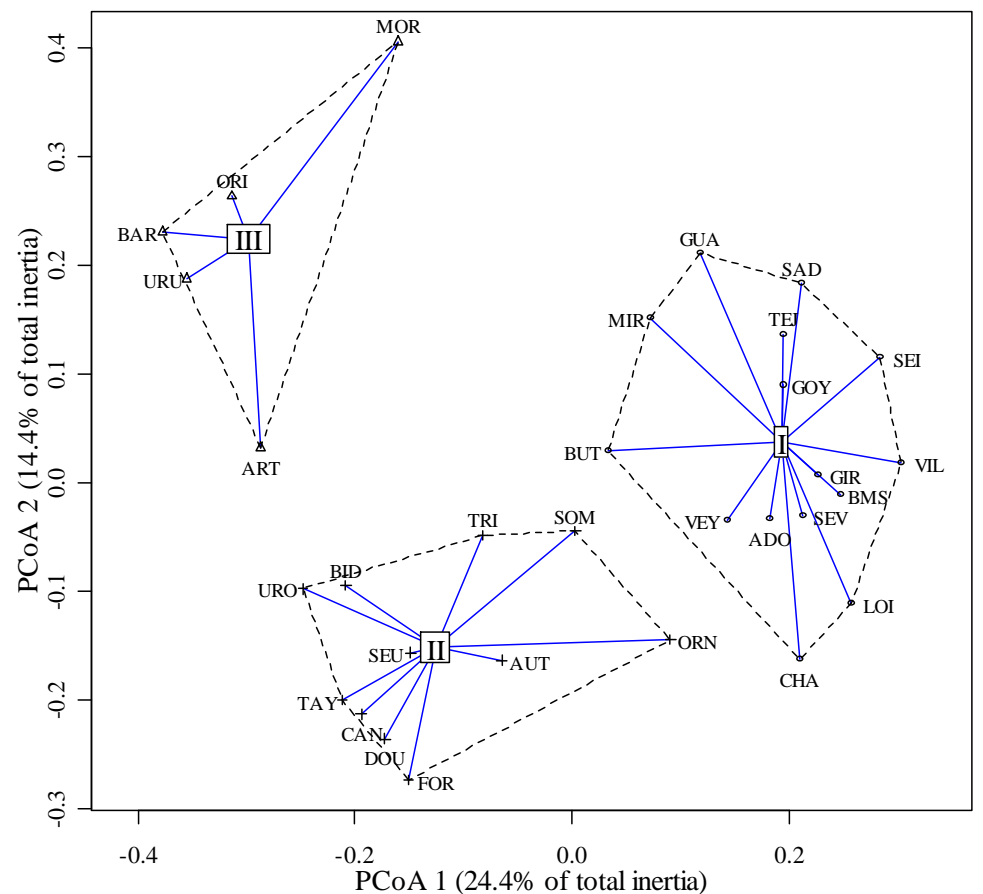

b/

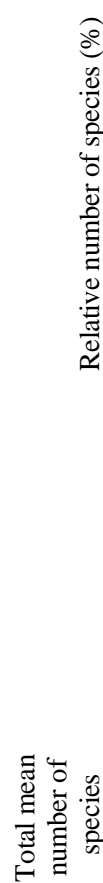

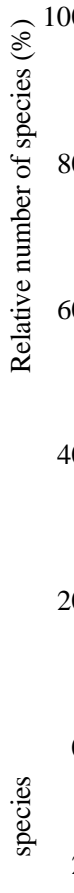

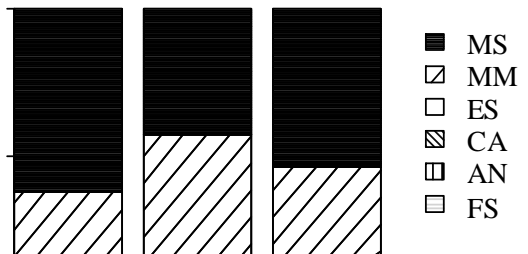

60
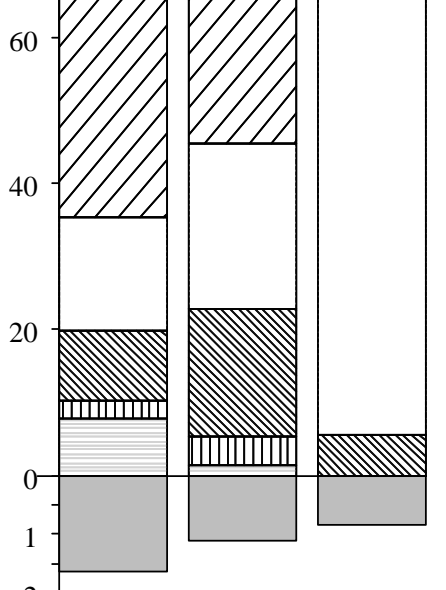

I

II

III 
Author produced version of the article published in

Estuarine Coastal and Shelf Science, 2010, vol. 88, p. 329 - 338

The original publication is available at http://sciencedirect.com/

doi : 10.1016/j.ecss.2010.04.010

Fig. 4 :

2

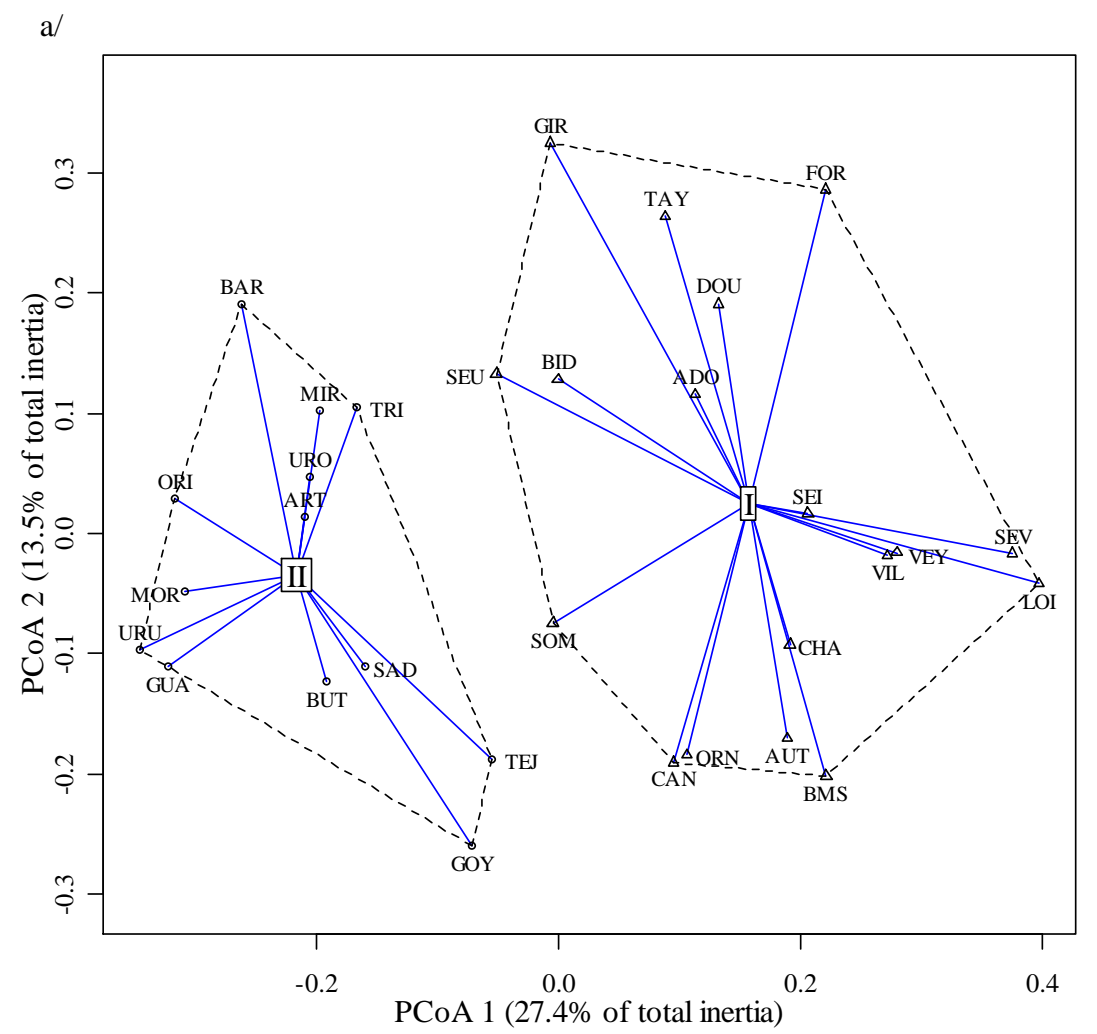

b/

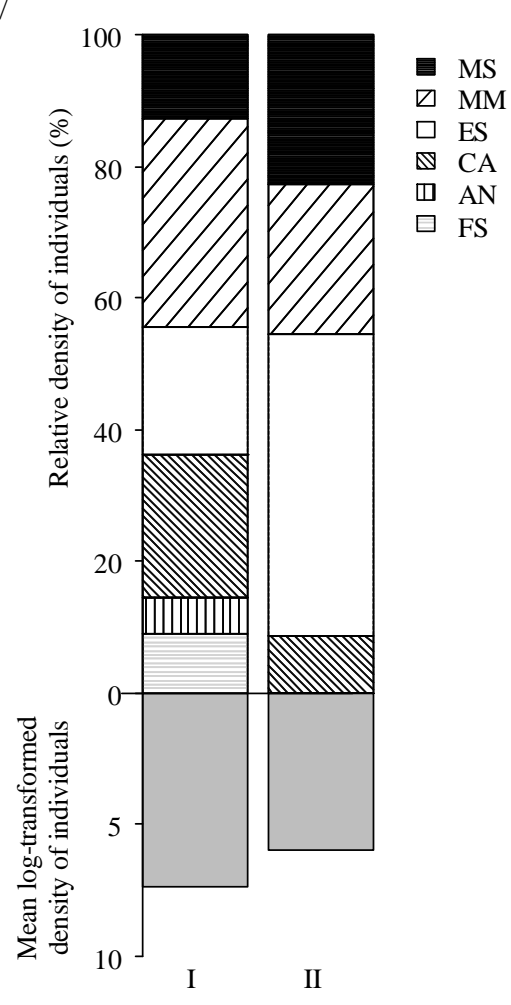

